\title{
DIGITALCOMMONS
}

@WAYNESTATE —

Wayne State University

9-10-2013

\section{Analysis of uniparental lineages in two villages of Santiago del Estero, Argentina, seat of "Pueblos de Indios" in colonial times}

\author{
Maia Pauro \\ Universidad Nacional de Córdoba, Argentina \\ Angelina García \\ Universidad Nacional de Córdoba, Argentina \\ Rodrigo Nores \\ Universidad Nacional de Córdoba, Argentina \\ Darío A. Demarchi \\ Universidad Nacional de Córdoba, Argentina, demarchi@ffyh.unc.edu.ar
}

\section{Recommended Citation}

Pauro, Maia; García, Angelina; Nores, Rodrigo; and Demarchi, Darío A., "Analysis of uniparental lineages in two villages of Santiago del Estero, Argentina, seat of "Pueblos de Indios" in colonial times" (2013). Human Biology Open Access Pre-Prints. Paper 33.

http://digitalcommons.wayne.edu/humbiol_preprints/33

This Open Access Preprint is brought to you for free and open access by the WSU Press at DigitalCommons@WayneState. It has been accepted for inclusion in Human Biology Open Access Pre-Prints by an authorized administrator of DigitalCommons@WayneState. 


\title{
Analysis of uniparental lineages in two villages of Santiago del Estero, Argentina, seat of "Pueblos de Indios" in colonial times
}

\author{
${ }^{1}$ Maia Pauro, ${ }^{1}$ Angelina García ${ }^{1}$, Rodrigo Nores ${ }^{1}$, and Darío A. Demarchi ${ }^{1}$
}

${ }^{1}$ Instituto de Antropología de Córdoba (IDACOR), CONICET - Universidad Nacional de Córdoba. Córdoba 5000, Argentina.

Running title: Native American lineages in Santiago del Estero, Argentina

KEY WORDS: South America, Parental lineages, mtDNA HVR-I, Y Chromosome, Native Americans, Pueblos de Indios

Corresponding author: Darío A. Demarchi

IDACOR - CONICET/UNC

Museo de Antropología

Hipólito Yrigoyen 174, Córdoba 5000. Argentina

E-mail: demarchi@ffyh.unc.edu.ar 


\section{Abstract}

Based on the analysis of the mitochondrial control region and seven biallelic markers of the $\mathrm{Y}$ Chromosome, we investigated the genetic composition of two rural populations of southern Santiago del Estero, Argentina, that were seats in colonial times of "pueblos de indios", a colonial practice that consisted of concentrating the indigenous populations in organized and accessible settlements, to facilitate Christianizing and policing.

We found the Native American Y chromosome haplogroup Q1a3a in only 11\% (3/27) of the males. Haplogroup R, common in European populations, is the most frequent haplogroup in Santiago del Estero (55\%). In contrast, the persistence of Native American maternal lineages is extremely high (95\%). This finding is most likely due to the low incidence in that region of the 20th century European wave of migration and by the existence of "pueblos de indios" from 1612 to the first decades of the 19th century. In contrast to archeological records that suggest Santiago del Estero late pre-Hispanic groups were strongly influenced by the Andean world, we did not find genetic evidence in support of significant gene flow. On the other hand, these populations share many mtDNA HVRI haplotypes with other populations from the Sierras Pampeanas (particularly with Córdoba), and the Gran Chaco regions. 
Santiago del Estero, founded by Francisco de Aguirre in 1553, is the oldest city that is definitely rooted in the current territory of Argentina. Located on the border between the western farmers of the Andean valleys and the hunter-gatherers of the Gran Chaco, this settlement was part of the Spanish colonization process of the northwestern region of Argentina during the 16th century. The landscape of Santiago del Estero province is dominated by plains, crossed diagonally by the rivers Dulce and Salado, which originate in the Andean foothills. The south is the only portion of the province that includes low hills, connected to the Sierras Pampeanas, a mountain system that occupies the central- northwestern portion of Argentina (see Figure 1).

In pre-Hispanic times, the valleys between these rivers were centers of sedentary groups related to the Andean world (Bonnin and Laguens, 2000; Taboada and Angiorama, 2010).

Archaeological evidence suggests that these groups collaborated with the Inca Empire in the late pre-Hispanic period (Palomeque, 2000).

Despite this unquestionable cultural influence, craniometric evidence suggests low biological affinities between Santiago del Estero and ancient Andean populations that inhabited northwestern Argentina. However, a close resemblance was observed with other human groups that inhabited the central region of Argentina, in the current territory of Córdoba province (Cocilovo, 1984; Cocilovo and Di Rienzo, 1984-1985; Fabra and Demarchi, 2012).

The historical records show that the Spaniard Conquest and colonization began a series of transformations that affected the whole "Indian World." While most of the populations were unstructured and even "disappeared" quickly (Piana, 1992), others survived and persisted reduced in "Pueblos de Indios" (Indian villages) within the system of colonial domination (Olaneta Castro, 2003). As expressed by Farberman (2008), the Indian villages under the encomienda regime became colonial corporations as pueblos de indios, when Francisco de 
Alfaro's ordinances were enacted in 1612. The most important measures were the creation of reducciones with communal lands, traditional Indian authorities and alcaldes (major) as well as the replacement of the personal service for tributo (taxes). Briefly, this colonial practice consisted in the concentration of the native population in organized and accessible settlements, to facilitate both for Christianizing and policing.

In Argentina, the first half of the 19th and beginning of the 20th century was marked by a population expansion as result of massive European immigration (Pellegrino, 2002). Between 1880 and 1935, about 3.4 millions of Europeans, mainly from Spain and Italy, arrived to the ports of Buenos Aires. It is estimated that between 50 and $75 \%$ of them settled in the country, mainly in the cities of the Pampean and Patagonian regions (Sánchez Albornoz, 1994). On the other hand, this massive European migration had little impact in Santiago del Estero. In 1928, only $3.5 \%$ of its population were foreigners (Grosso, 2008).

Molecular markers, particularly those located on the mitochondrial DNA and the nonrecombinant portion of Y Chromosome, are useful for the study of the genetic composition and biological history of neo-American populations, in which it is possible to infer the substantial contribution of the Native American component, but where its members have lost their ethnic identity -as a result of dramatic historical, cultural and social changes (García and Demarchi, 2009). Thus, it is possible to observe the preservation of a substantial proportion of the original gene pool in contemporary populations, despite the disappearance of a large number of American ethnic groups after centuries of European colonization (Sans, 2000; Rocco et al., 2002; Wang et al., 2008; García and Demarchi, 2009; Pauro et al., 2010; Bobillo et al., 2010; Corach el al., 2010, Cardoso et al., 2013). 
Currently, there is no information about the incidence and distribution of parental Native American lineages for the human population of Santiago del Estero. This province of northwestern Argentina has a large archeological tradition and documented settlements of several ethnic groups that survived for centuries after the arrival of the Spaniards.

In this study we investigated the genetic composition of two rural populations of southern Santiago del Estero, Villa Atamisqui and Sumampa, based on the analysis of mitochondrial DNA sequences and Y-Chromosome markers. Our particular interest in the study of the genetic history of these two villages lies in the fact that both populations were seats in colonial times of "pueblos de indios". Additional interest arises in the fact that the census records of 1778, ordered by the king Carlos III, were particularly contrasting for these two parishes: while the Soconcho parish (currently Villa Atamisqui) was composed of an Indian majority, most of the inhabitants of Sumampa were of African origin (Grosso, 2008).

The objectives of this study were to investigate: 1) whether or not the contrasting composition of both populations, recorded in the census of 1778 , would be reflected in the genetic composition of the contemporary populations; 2) the proportion of Native American lineages that still survive in these villages; 3 ) whether or not the pattern of biological relationships, observed from craniometric analyses, relating Santiago del Estero and the ancient populations of Córdoba, is supported by molecular evidence and; 4) the phylogeographic and phylogenetic relationships of the Santiago del Estero population -with other Native American groups from the Southern Cone of South America, based on the analysis of the mitochondrial hypervariable region I (mtDNA HVR-I). 


\section{Materials and Methods}

\section{The Sample}

A total of 85 samples from unrelated individuals were collected at public hospitals of Sumampa $\left(29.38^{\circ} \mathrm{S}, 63.47^{\circ} \mathrm{W} ; \mathrm{n}=29,11\right.$ males and 18 females $)$, and Villa Atamisqui $\left(28.48^{\circ} \mathrm{S}, 63.8^{\circ} \mathrm{W}\right.$; $\mathrm{n}=56,16$ males and 40 females). All participants were informed of the objectives of this study and consented to donate buccal swabs to be used anonymously in the execution of this nonprofit scientific investigation. With the aim of defining and limiting the sample, we considered only individuals with at least three generations at the specific birthplaces. The information gathered in the field regarding the birthplaces of subjects and their parents indicated that the inhabitants of these villages present low to moderate mobility, limited to their region of origin.

In order to investigate the affinities in mtDNA lineages distribution between the studied populations and other Native American populations from the Southern Cone of South America, we selected from the literature 38 population samples representing different geographicecological regions (Table 1).

\section{Laboratory Methods}

Genomic DNA was extracted from cheek swabs using the Accuprep Genomic DNA Purification Kit (GenBiotech). The 27 male samples were analyzed with seven biallelic markers located in the nonrecombinant region of the Y Chromosome. These polymorphisms were defined by the presence or absence of the characteristic mutation for the following markers: M3 (Underhill et al., 1996), M207 (Su et al., 1999), M168 and M9 (Underhill et al., 2001), M89 (Karafet et al., 1999), M2 (Seielstad et al., 1994), and YAP (Hammer, 1995). All polymorphisms were analyzed 
using standard PCR protocols with minor modifications and then digested with restriction enzymes (except for the insertion YAP). The amplification strategy was carried out following a hierarchical amplification protocol (Hammer et al., 2001; Jobling et al., 2004; Karafet et al., 2008), which means that each subject was not genotyped for all markers. The genotyped samples were assigned to haplogroups, useful for identifing geographic origins (Karafet et al., 2008; Jobling and Smith, 2003).

The mtDNA non-coding Control Region was amplified for all 85 samples using the following specific primers: F15811 (5' TCATTGGACAAGTAGCATCC 3'), and R698 (5' GCATGTGTAATCTTACTAAGAG 3'). The amplification reaction was performed in a Biometra T-Personal thermocycler in a volume of $50 \mathrm{ul}$ under the following conditions: an initial denaturation step of $94^{\circ} \mathrm{C}$ for 5 minutes, followed by 40 cycles with temperatures of $94^{\circ} \mathrm{C}$ for 1 minute, $52^{\circ} \mathrm{C}$ for 1 minute and $72^{\circ} \mathrm{C}$ for 1.5 minutes, with a final extension step of 5 minutes at $72^{\circ} \mathrm{C}$. Verification and quality control of PCR amplification was performed by gel electrophoresis on 2\% agarose, stained with GelStar (Lonza) and visualized with UV light. The amplified products were sent to Macrogen Inc. (Seoul, Korea) for purification and automatic sequencing, using primers F15811 and F16475 (5' TAGCTAAAGTGAACTGTATCC 3'). The sequences were corrected manually and then aligned and compared with the revised Cambridge Reference Sequence (Andrews et al., 1999) using the program MEGA 4.0 (Tamura et al., 2007). Haplogroups were defined by the presence of specific mutations in the Control Region following Tamm et al. (2007) for Native American lineages, and Haplogrep (Kloss-Brandstaetter et al., 2010) and Phylotree (van Oven and Kayser, 2008) for Non Native American lineages. 


\section{Data Analysis}

Heterogeneity in mtDNA and Y Chromosome haplogroups distribution between both Santiago del Estero samples was evaluated using the Exact Test of population differentiation (Raymond and Rousset, 1995). Population genetic structure was further investigated by mean of the analysis of molecular variance (AMOVA) (Excoffier et al., 1992), as implemented in the program Arlequin, version 3.11 (http://cmpg.unibe.ch/software/arlequin3). This program was also used to calculate pairwise genetic distances, Kimura 2-parameters (Kimura, 1980), with nonzero significance evaluated by a randomization test. From the distance matrix, a genetic map was constructed by means of multiple dimensional scaling (Kruskal, 1964). For the analyses including Santiago del Estero and the other 38 Southern Cone population samples (Table 2) we considered the mtDNA sequences of HVR-I between nucleotide pairs (np) 16051-16362. A median-joining network for each haplogroup was constructed using the technique of Bandelt et al. (1995) with the program Network (version 4.6.1.1), including mtDNA sequences between 16027-16362np (HVR-I) from the 13 populations of Argentina (Table 1). After a careful screening of published data representing populations from the Southern Cone, we observed that the Santiago del Estero samples only share haplotypes with other Argentinean populations excepting in the case of nodal haplotypes. As the full median network can contain unnecessary median vectors and links, it was subjected to a maximum parsimony analysis to resolve ambiguities in the dataset, using the three criteria proposed by Crandall and Templeton (1993): frequency, topology, and geography, based on predictions from the coalescent theory. 


\section{Results}

\section{Paternal lineages}

The Native American haplogroup Q1a3a is present in only 11.1\% (3/27) of the males of the total sample (1/11 from Sumampa, and 2/16 from Villa Atamisqui). Haplogroup R, the most frequent haplogroup in Europe (Jobling and Tyler-Smith, 2003), and in Argentinean urban populations (Corach et al., 2010; Bailliet et al., 2011), is also frequent in Sumampa and Villa Atamisqui (63.6\% and 50\%, respectively). Haplogroup F, common in both European and Middle Eastern/North African populations, is well represented in Villa Atamisqui (6/16) but not in Sumampa (1/11). Finally, two individuals from Sumampa carry the haplogroup DE, but do not represent the derivative state for M2, being therefore most likely of European origin. Observed differences in Y Chromosome haplogroups distribution between samples are not statistically significant $(\mathrm{p}=0.156)$.

\section{Maternal lineages}

\section{Mitochondrial haplogroups distribution}

Two individuals from Villa Atamisqui and one from Sumampa represent European lineages, whereas only one subject, from Villa Atamisqui, represents mtDNA of African origin. The other 81 subjects possess Native American mtDNAs. It is interesting to highlight the extremely high incidence of Native American mitochondrial haplogroups in these two rural towns $(96.6 \%$ in Sumampa, and $94.6 \%$ in Villa Atamisqui), particularly in contrast with what we found for paternal haplogroups. In table 2 we present the Native American mtDNA haplogroups distribution by sample. The most frequent haplogroups in both samples are C1 and D1. Although haplogroup $\mathrm{C} 1$ is more frequent in Villa Atamisqui and haplogroup D1 has the highest incidence 
in Sumampa, differences are not statistically significant $(p=0.245)$. For this reason, in further analyses both samples will be combined and considered as one, Santiago del Estero population (SGO).

\section{Analysis of mtDNA sequences}

Fifty nine different haplotypes were found among the 81 subjects that possess Native American mtDNAs (see Appendix 1). Below we provide a description and comments about the distribution and phylogeographic relationships of the mtDNA haplotypes found in Santiago del Estero and other 12 populations from Argentina, based on HVR-I sequences (Table 3). Networks for haplogroups $\mathrm{C} 1$ and D1 are presented in Figure 3 and Figure 4. Networks for haplogroups A2 and $\mathrm{B} 2$ are not shown because they do not present any geographic structure that could help in clarifying phylogeographic relationships.

Haplogroup A2. Most of the individuals (8/15) represent the nodal motif A2. There are two haplotypes shared with other populations: h2 shows a transition in site 16189 (considered as hotspot, Soares et al., 2009) and h3 lacks the diagnostic site 16111, pattern already observed in individuals from Córdoba (García, 2011), Mapuches from the Argentinean Patagonia (Ginther et al., 1993), and one Pilagá from the Gran Chaco region (Cabana et al., 2006).

Haplogroup B2. Three individuals present the nodal haplotype and the other 5 present several mutational steps from the nodal. One haplotype (h7) is shared with three individuals from Córdoba (García, 2011). Partial matches for h6 and h9 were found in 6 individuals from Azampay (province of Catamarca; Ramallo, 2010), and in 7 of the 19 ancient samples from the Pampa Grande site (province of Salta), dated at 1300 BP (Carnese et al., 2010, not included on the network). Other two partial matches (at one mutational step) were found for the $\mathrm{h} 11$ in one Toba and one Wichí from the Gran Chaco (Cabana et al., 2006). 
Haplogroup C1 (figure 3). Most of the individuals included in the haplogroup C1 $(\mathrm{n}=36)$

present nodal haplotypes for C1b (7 individuals, transition at 493 is not included in the network) and C1d (11), widely shared with other South American populations. There are two haplotypes (h14 and h21) shared with individuals from Gran Chaco populations (Cabana et al., 2006), one shared with Córdoba (h15, García, 2011) and other (h16) shared with both populations.

Haplogroup D1 (figure 4). The nodal haplotype D1 was found in only one individual. Most of the subjects $(15 / 22)$ assigned to the haplogroup D1 belong to the recently defined subhaplogroup D1j (Bodner et al., 2012), that is characteristic of other populations of central Argentina, as Córdoba and San Luis (García et al., 2012), and Catamarca (Tamm et al., 2007). H26, found in 5 individuals from Santiago del Estero, was already observed in 3 individual from Córdoba (García, 2011) and two individuals from Gran Chaco populations (Cabana et al., 2006). Finally, h28 is shared with two inhabitants of Córdoba (García et al., 2012), and one Mapuche from the Argentinean Patagonia (de Saint Pierre et al., 2012).

In summary, excepting in the case of nodal haplotypes, the samples from Santiago del Estero share several haplotypes with populations from the Sierras Centrales (mostly from Córdoba), and a few haplotypes with the Gran Chaco populations, revealing a strong geographic structure.

\section{Distance Analysis}

The bidimensional plot representing variation in mtDNA HVR-I among 39 population samples from the Southern Cone, based on the Kimura 2-parameters distances (Figure 2), reveals some geographic structure. The subtropical forest tribes, with high frequency of haplotypes included in haplogroup A2, are scattered along the second axis at the extreme right side of the plot. The Gran Chaco, lowlands of Bolivia, and Tierra del Fuego-Patagonia samples fall along the first axis, more or less around the center of the cluster but also exhibiting some geographic structure. 
Ayoreo (AYO) and Aché (ACHE), two populations that have experienced marked diversity reduction, most probably due to founder effect, are found as outliers on the left and the top borders of the plot, respectively. Of the particular interest in this study, we observe that 4 of the 5 samples from the Sierras Pampeanas region cluster close to each other, showing the sample of Santiago del Estero has the shortest distance with Córdoba. On the left side of the plot, the fifth sample of the region (Azampay, AZA), is close to its neighbor Andean populations, all characterized by high incidence of B2 lineages.

\section{Analysis of molecular variance}

The analysis of molecular variance for Native American lineages based on mtDNA HVR-I sequences among Southern Cone populations is presented in Table 4. In first place, we introduced in the analysis all populations together, separating them into six cultural-geographic groups: Sierras Pampeanas, Tierra del Fuego-Patagonia, Gran Chaco, Subtropical Forests, Central Andes, and Lowlands of Bolivia, using data from the populations listed in Table 1. As is a rule in human populations, most of the variance observed was due to the intrapopulation variability. At the first geographical level, considering all the 39 population samples, it can be seen that the among-groups variation is smaller than the value for the among-populations/withingroups variance. Both values are relatively high and statistically significant. When we removed from the analysis the two outliers observed in the distance analysis (Ayoreo and Aché), the among-groups variation became larger than the among-populations/within-groups variance, since the extreme differentiation of these two populations inflate the within-groups variance. Separate analyses for each region reveal that the Subtropical Forests populations are substantially more variable than the other Southern Cone groups, a fact that had previously been observed (Demarchi et al., 2005; Tarazona-Santos et al., 2001). On the other extreme, the populations from the 
lowlands of Bolivia show small, non significant, differentiation. The Sierras Pampeanas populations present intermediate, statistically significant, differentiation. However, a more detailed analysis reveals that the $\mathrm{F}_{\mathrm{ST}}$ value between Santiago del Estero and Córdoba is extremely low $\left(\mathrm{F}_{\mathrm{ST}}=0.0016, \mathrm{p}=0.291\right)$, less than tenfold observed between Santiago del Estero and the other populations of the region (data not shown).

\section{Discussion}

This work constitutes the first study that examines the genetic variability of human populations in the province of Santiago del Estero. In agreement with what has already been found in numerous other studies carried out in Latin American populations, the survival of indigenous paternal lineages in this population is relatively low. In contrast, the persistence of maternal lineages of Native American origin is extremely high. This is the typical pattern found in Latin American populations, a consequence of asymmetric gene flow, resulting in a population composed of a paternal component mostly European and a predominantly Native American maternal component [see Wang et al. (2008) and literature therein]. However, in spite of this precedent, it is still remarkable to find that the maternal gene pool of the populations of southern Santiago del Estero is almost exclusively of American origin (95\%), a proportion even higher than what it is found in some Native American settlements. This finding is most likely due to the relatively low incidence of the 20th century European migratory wave in this region and the survival for long time - from 1612 to early 19th century - of "pueblos de indios" in these two villages (Palomeque, 2000; Grosso, 2008).

The census ordered by Carlos III, in 1778, recorded the population using the categories "Spaniards", "Indians", "free Negroes, Zambos, and Mulattoes", and "Slaves". The records show 
that Soconcho (currently Villa Atamisqui) and Sumampa parishes were particularly contrasting: while Soconcho parish was composed by an Indian majority (94\%), Sumampa presented a majority of African descents $(90 \%$, mostly within the category "free Negroes, Zambos, and Mulattoes") (Grosso, 2008). Despite this apparently contradictory history, at present we did not observe genetic differences between the two populations. Whereas Villa Atamisqui shows an incidence of maternal Native American lineages (similar to that recorded as Indians in the 1778's census in the former Soconcho parish), the high incidence of African descendants in Sumampa, reported in that census, is not reflected in the gene pool of the current population. Trying to shed light on that marked lack of agreement, Grosso (2008) states that, in colonial times, those Indians who did not pay tribute to the Spanish crown (because they were free or were not living at the time in their village of origin), were usually included in the loosely defined census category "free Negroes, Zambos, and Mulattoes". Under the same scenario, the absence of African lineages found in the current population of Sumampa could be reflecting an inaccurate categorization that denied the existence of free Indians, incorporating them into the category "free Negroes, Zambos, and Mulattoes". Even though the censuses carried out in colonial times enable us to obtain valuable information, they should be considered with extreme care (Faberman 2008). At the regional level, and in despite the archeological record which suggests that Santiago del Estero late pre-Hispanic groups were strongly influenced by Andean cultures (Bonnin and Laguens, 2000; Palomeque, 2000; Taboada and Angiorama, 2010), we did not found any genetic evidence that this relationship was associated to a significant gene flow--at least in the populations that occupy the southern portion of the province. On the other hand, these populations share many haplotypes with other Sierras Pampeanas populations, particularly with Córdoba. There are no significant statistical differences for considering them as separate 
populations, although Santiago del Estero populations, unlike Córdoba, shares several haplotypes with the Gran Chaco populations,-- probably as result of gene flow due to the closer geographic distances.

It is particularly interesting to note the high incidence of the recently described subhaplogroup D1j in the Santiago del Estero population (19\%). The high frequency of this lineage across central and northwestern Argentina was already reported by our group (García et al., 2012). That study, which included the same D1 sequences analyzed in this work, strongly supported the hypothesis of a local origin for subhaplogroup D1j. The existence of a putative ancestral lineage, carrying the transitions 152 16311, present in 4 of the other D1 haplotypes, and only found in this region, give additional support for a scenario of local origin for $\mathrm{D} 1 \mathrm{j}$. As mentioned in that study, the restricted geographical distribution of $\mathrm{D} 1 \mathrm{j}$ in other regions of South America suggests the existence of an ancient metapopulation (with this lineage serving as its genetic signature) covering the Sierras Pampeanas (García et al., 2012). This close genetic relationships is reflected in the bidimensional plot among four of the five populations of the Sierras Pampeanas region.

Acknowledgments. We thank the participants for their cooperation during the collection of biological samples. Many thanks to Michael H. Crawford for a critical review of an earlier version of the manuscript. Thanks also to Mariana Fabra who helped during the fieldwork. Angelina García and Rodrigo Nores are postdoctoral fellows, Maia Pauro is a doctoral fellow, and Darío Demarchi is a Research Career Member of the Consejo Nacional de Investigaciones Científicas y Técnicas de la República Argentina (CONICET).

This investigation was funded by ANPCyT through grant PICT 2007-1549, by CONICET through grant PIP 2010-1, and by SECyT (Universidad Nacional de Córdoba). 


\section{Literature cited}

Bailliet G, Ramallo V, Muzzio M et al. 2011. Antecedentes y nuevos aportes en el estudio del Cromosoma Y en poblaciones humanas sudamericanas. Journal of Basic and Applied Genetics. 22:1-9.

Bandelt HJ, Forster P, Sykes BC, Richards MB. 1995. Mitochondrial portraits of human populations using median networks. Genet Soc Am 141:743-753.

Barbieri C, Heggarty P, Castri L et al. 2011. Mitochondrial DNA Variability in the Titicaca Basin: Matches and Mismatches with Linguistics and Ethnohistory. American Journal of Human Biology. 23:89-99.

Bert F, Corella A, Gené M et al. 2004. Mitochondrial DNA diversity in the Llanos de Moxos: Moxo, Movima and Yuracare Amerindian populations from Bolivia lowlands. Annals of Human Biology. 31:9-28.

Bobillo MC, Zimmermann B, Sala A, Huber G, Röck A, Bandelt H-J, Corach D, Parson W. 2010. Amerindian mitochondrial DNA haplogroups predominate in the population of Argentina: towards a first nationwide forensic mitochondrial DNA sequence database. Int J Legal Med 124:263-268.

Bodner M, Zimmermann B, Röck A et al. 2012. Southeast Asian diversity: first insights into the complex mtDNA structure of Laos. BCM Evolutionary Biology. 11:49.

Bonnin M, Laguens, A. 2000. Esteros y algarrobales. Las sociedades de las sierras centrales y la llanura santiagueña. En: Nueva historia Argentina, Tomo I. Editorial Sudamericana, Buenos Aires. 
Cabana GS, Merriwether DA, Hunley K, Demarchi DA. 2006. Is the genetic structure of Gran Chaco populations unique? Interregional perspectives on native South American mitochondrial DNA variation. American Journal of Physical Anthropology. 131:108-119.

Cardoso S, Palencia-Madrid L, Valverde L et al. 2013. Mitochondrial DNA control region data reveal high prevalence of Native American lineages in Jujuy province, NW Argentina. Forensic Science International: Genetics - 22 February (10.1016/j.fsigen.2013.01.007) Carnese FR, Mendisco F, Keyser C et al. 2010. Paleogenetical study of pre-Columbian samples from Pampa Grande (Salta, Argentina). Am J Phys Anthropol 141(3):452-462.

Castro Olañeta I. 2003. Transformaciones y continuidades de sociedades indígenas en el sistema colonial El caso del pueblo de indios de Quilino a principios del siglo XVII. Unpublished Bachelor thesis. Universidad Nacional de Córdoba, Córdoba, Argentina.

Cocilovo JA. 1984. Una nueva aproximación al conocimiento de la población prehistórica de la provincia de Córdoba. Comechingonia, Año 2, Nro.3:85-104.

Cocilovo JA y Di Rienzo J. 1984-1985. Un modelo biológico para el estudio del doblamiento prehispánico del territorio argentino. Correlación fenético-espacial. Relaciones de la Sociedad Argentina de Antropología, Tomo XVI: 119-135, Buenos Aires, Argentina. Corach D, Lao O, Bobillo C et al.. 2010. Inferring continental ancestry of argentineans from Autosomal, Y-chromosomal and mitochondrial DNA. Annals Human Genetics, Vol.74, No.1, pp.65-76.

Crandall KA, Templeton AR. 1993. Empirical tests of some predictions from coalescent theory with applications to intraspecific phylogeny reconstruction. Genetics 134:959-969.

Demarchi, D., F. Salzano, M. Altuna et al. 2005. APOE polymorphism distribution among Native Americans and related populations. Ann Hum Biol, 32 (3): 351-365. 
De Saint Pierre M, Bravi CM, Motti JM et al. 2012. An alternative model for the early peopling of southern South America revealed by analyses of three mitochondrial DNA haplogroups. PLoS ONE 7(9): e43486. doi:10.1371/journal.pone.0043486

Dornelles CL, Battilana J, Fagundes NJ et al. 2004. Mitochondrial DNA and Alu insertions in a genetically peculiar population: the Ayoreo Indians of Bolivia and Paraguay. American Journal of Human Biology. 16:479-488.

Excoffier L, Smouse P, Quattro J. 1992 Analysis of molecular variance inferred from metric distances among DNA haplotypes: Application to human mitochondrial DNA restriction data. Genetics 131:479-491.

Faberman J. 2008. Santiago del Estero y sus pueblos de indios. De las ordenanzas de Alfaro (1612) a las guerras de independencia. Andes 19: 225-250.

Fabra M, Demarchi DA. 2012. Morfología craneofacial y estructura genética en poblaciones del centro de Argentina. Revista Argentina de Antropología Biológica. 14(1):45-56.

Fuselli S, Tarazona-Santos E, Dupanloup I et al. 2003. Mitochondrial DNA diversity in South America and the genetic history of Andean highlanders. Molecular Biology and Evolution. 20:1682-91.

García A, Demarchi DA. 2009. Incidence and Distribution of Native American mtDNA Haplogroups in Central Argentina. Human Biology. 81(1):59-69.

García A. 2011. Historia evolutiva de las poblaciones originarias del actual territorio de la provincia de Córdoba: evidencias moleculares. Unpublished Ph.D. thesis. Universidad Nacional de Córdoba, Argentina.

García A, Pauro M, Nores R et al. 2012. Phylogeography of Mitochondrial Haplogroup D1: An Early Spread of Subhaplogroup D1j from Central Argentina. American Journal of Physical Anthropology. 149(4):583-90. 
Gaya-Vidal M, Moral P, Saenz-Ruales N et al. 2011. mtDNA and Y-Chromosome Diversity in Aymaras and Quechuas From Bolivia: Different Stories and Special Genetic Traits of the Andean Altiplano Populations. Am J Phys Anthropol. 145:215-230.

Ginther C, Corach D, Penacino GA et al. 1993. Genetic variation among the Mapuche Indians from the Patagonian region of Argentina: mitochondrial DNA sequence variation and allele frequencies of several nuclear genes. In: Pena S, Chakraborty R, Epplen J, Jeffreys A, editors. DNA fingerprinting: state of the science. Basel: Birkhauser Verlag. p 211-219.

Grosso JL. 2008. Indios muertos, negros invisibles. Encuentro Grupo Editor, Córdoba, Argentina. Hammer MF, Horai S. 1995. Y chromosomal DNA variation and the peopling of Japan. American Journal of Human Genetics. 56(4):951-962.

Hammer MF, Karafet TM, Redd AJ et al. 2001. Hierarchical patterns of global human Ychromosome diversity. Molecular Biology Evolution. 18:1189-1203.

Jobling MA, Tyler-Smith C. 2003. The human Y chromosome: An evolutionary marker comes of age. National Review of Genetics, Vol.4, pp.598-612.

Jobling MA, Hurles ME, Tyler-Smith C. 2004. Human Evolutionary Genetics: Origins, Peoples and Disease London/New York: Garland Science Publishing.

Karafet TM, Zegura SL, Posukh O et al. 1999. Ancestral Asian source(s) of New World Ychromosome founder haplotypes. American Journal of Human Genetics. 64:817-831.

Karafet TM, Mendez FL, Meilerman MB et al. 2008. New binary polymorphisms reshape and increase resolution of the human Y chromosomal haplogroup tree. Genome Research. $18: 830-838$.

Kimura M. 1980. A simple method for estimating evolutionary rate of base substitution through comparative studies of nucleotide sequences. J. Mol. Evol. 16:111-120. 
Kloss-Brandstaetter A, Pacher D, Schoenherr S et al. 2010. HaploGrep: a fast and reliable algorithm for automatic classification of mitochondrial DNA haplogroups http://www.haplogrep.uibk.ac.at doi: 10.1002/humu.21382

Kruskal J. 1964. Multidimensional scaling by optimizing goodness of fit to a nonmetric hypothesis. Psychometrika. 29:1-27.

Lewis CM, Lizárraga B, Titi RY et al. 2007. Mitochondrial DNA and the Peopling of South America. Human Biology, 79 (2): 159-178.

Marrero AR, Silva-Junior WA, Bravi CM et al. 2007. Demographic and Evolutionary Trajectories of the Guarani and Kaingang Natives of Brazil. American Journal of Physical Anthropology.132:301-310.

Moraga Ml, Rocco P, Miquel JF et al. 2000. Mitochondrial DNA polymorphisms in Chilean aboriginal populations: implications for the peopling of the southern cone of the continent. American Journal of Physical Anthropology. 113(1):19-29.

Palomeque S. 2000. El mundo indígena. Siglos XVI-XVIII. En: Nueva historia Argentina, Tomo II. Editorial Sudamericana, Buenos Aires.

Pauro M, García A, Bravi CM, Demarchi DA. 2010. Distribución de haplogrupos mitocondriales alóctonos en poblaciones rurales de Córdoba y San Luis. Revista Argentina de Antropología Biológica. 12(1):47-55.

Pellegrino A. 2002. La migración internacional en América Latina. Tendencias y perfiles de los migrantes. Conferencia Hemisférica sobre Migración Internacional: Derechos Humanos y Trata de Personas. Santiago de Chile.

Piana J. 1992. Los indígenas de Córdoba bajo el régimen colonial 1570-1620. Pp. 362. Dirección General de Publicaciones, Universidad Nacional de Córdoba, Argentina. 
Ramallo V. 2009. Caracterización del perfil genético de la población actual de Azampay,

Catamarca. Unpublished Ph.D. thesis. Universidad Nacional de la Plata, Argentina.

Raymond M, Rousset F. 1995 An exact test for population differentiation. Evolution. 49:12801283.

Rocco P, Morales C, Moraga M et al. 2002. Composición genética de la población chilena:

Distribución de polimorfismos de DNA mitocondrial en grupos originarios y en la población mixta de Santiago. Revista Médica de Chile. 130:125-131.

Sala A, Argüelles CF, Marino M et al. 2010. Genetic Analysis of Six Communities of Mbyá-

Guaraní Inhabiting Northeastern Argentina by Means of Nuclear and Mitochondrial Polymorphic Markers. Human Biology 82(4):433-456.

Sánchez Albornoz N. 1994. La población de América Latina: desde los tiempos precolombinos al año 2025. Alianza Universidad. Madrid.

Sans M. 2000. Admixture studies in Latin America: from the 20th to the 21st century. Human Biology 72:155-177.

Schmitt R, Bonatto SL, Freitas LB et al. 2004. Extremely limited mitochondrial DNA variability among the Aché Natives of Paraguay. Annals of Human Biology. 31:87-94.

Seielstad MT, Hebert JM, Lin AA et al. 1994. Construction of human Y-chromosomal haplotypes using a new polymorphic A to G transition. Human Molecular Genetics. 3(12):2159-61.

Soares P, Ermini L, Thomson N et al. 2009. Correcting for purifying selection: an improved human mitochondrial molecular clock. American Journal of Human Genetics. 84:740-759.

Su B, Xiao J, Underhill P et al. 1999. Y-chromosome evidence for a northward migration of modern humans into Eastern Asia during the last Ice Age. American Journal of Human Genetics. 65:1718-1724. 
Taboada C, Angiorama C I. 2010. Metales, textilería y cerámica: tres líneas de análisis para pensar una vinculación entre los habitantes de la llanura santiagueña y el Tawantinsuyu. Memoria Americana. 18: 11-41

Tamm E, Kivisild T, Reidla M et al. 2007. Beringian Standstill and Spread of Native American Founders. PLoS ONE 2(9): e829. doi:10.1371/journal.pone.0000829

Tamura K, Dudley J, Nei M et al. 2007. MEGA4: Molecular Evolutionary Genetics Analysis (MEGA) software version 4.0. Molecular Biology and Evolution. 24:1596-1599.

Tarazona-Santos E, Carvalho-Silva DR, Pettener D et al. 2001. Genetic differentiation in South Amerindians is related to environmental and cultural diversity: evidence from the $\mathrm{Y}$ chromosome. Am J Hum Genet. 68(6):1485-96.

Underhill PA, Jin L, Zemans R et al. 1996. A pre-Columbian Y chromosome-438 T.G. specific transition and its implications for human evolutionary history. Proceedings of the National Academy of Sciences. USA. 93:196-200.

Underhill PA, Passarino G, Lin AA et al. 2001. The phylogeography of Y chromosome binary haplotypes and the origins of modern human populations. Ann Hum Genetics. 65:43-62.

Van Oven M, Kayser M. 2008. Updated comprehensive phylogenetic tree of global human mitochondrial DNA variation. Human Mutation; 386-394.

Wang S, Ray N, Rojas W et al. 2008. Geographic patterns of genome admixture in Latin American Mestizos. PLoS Genetics, 21;4(3):e1000037 
Table 1. Southern Cone populations included in the analysis, by geographic region.

\begin{tabular}{|c|c|c|c|c|c|c|}
\hline Population & Abbrev. & $\mathrm{N}$ & Region & Lat (S) & Long (W) & Reference \\
\hline Santiago del Estero & $\mathrm{SGO}$ & 81 & Sierras Pampeanas, Argentina & 28.75 & 63.38 & This work \\
\hline Córdoba & $\mathrm{CBA}$ & 180 & Sierras Pampeanas, Argentina & 31.23 & 64.11 & García 2011 \\
\hline San Luis & SL & 60 & Sierras Pampeanas, Argentina & 32.61 & 65.24 & García 2011 \\
\hline Wichí - Formosa & WFOR & 67 & Gran Chaco, Argentina & 24.00 & 62.20 & Cabana et al., 2006 \\
\hline Wichí - Chaco & $\mathrm{WCH}$ & 32 & Gran Chaco, Argentina & 24.60 & 61.50 & Cabana et al., 2006 \\
\hline Toba - Chaco & $\mathrm{TCH}$ & 43 & Gran Chaco, Argentina & 26.00 & 60.60 & Cabana et al., 2006 \\
\hline Toba - Formosa & TFOR & 24 & Gran Chaco, Argentina & 26.20 & 58.30 & Cabana et al., 2006 \\
\hline Pilagá & PIL & 38 & Gran Chaco, Argentina & 24.40 & 59.60 & Cabana et al., 2006 \\
\hline Catamarca & CAT & 25 & Sierras Pampeanas, Argentina & 28.28 & 65.46 & Tamm et al., 2007 \\
\hline Azampay - Catamarca & AZA & 118 & Sierras Pampeanas, Argentina & 27.36 & 67.05 & Ramallo 2009 \\
\hline Guarani - Misiones & GUAM & 121 & Subtropical Forests,Argentina & 25.83 & 54.33 & Sala et al., 2010 \\
\hline Mapuche & MAPAR & 90 & Patagonia, Argentina & 40.36 & 68.82 & Ginther et al., 1993; de Saint Pierre et al., 2012 \\
\hline Tehuelche & $\mathrm{TEH}$ & 29 & Patagonia, Argentina & 42.21 & 66.36 & de Saint Pierre et al., 2012 \\
\hline Fueguinos & GUE & 36 & Patagonia, Chile & 55.02 & 67.40 & Moraga et al., 2000; de Saint Pierre et al., 2012 \\
\hline Mapuche & MAPCH & 53 & Patagonia, Chile & 39.29 & 72.80 & Moraga et al., 2000; de Saint Pierre et al., 2012 \\
\hline Pehuenche & PEH & 66 & Patagonia, Chile & 37.43 & 71.16 & Moraga et al., 2000; de Saint Pierre et al., 2012 \\
\hline Kawesqar & KAW & 13 & Patagonia, Chile & 53.08 & 70.55 & Moraga et al., 2010 \\
\hline Atacama & ATA & 28 & Central Andes, Chile & 23.45 & 68.17 & de Saint Pierre et al., 2012 \\
\hline
\end{tabular}




\begin{tabular}{|c|c|c|c|c|c|c|}
\hline Guaraní M’byá & MBYA & 24 & Subtropical Forests, Brazil & 25.18 & 52.32 & Marrero et al., 2007 \\
\hline Guaraní Kaiowá & KAI & 120 & Subtropica Forests, Brazil & 23.06 & 55.12 & Marrero et al., 2007 \\
\hline Guaraní Nandeva & NAN & 56 & Subtropical Forests, Brazil & 23.48 & 54.30 & Marrero et al., 2007 \\
\hline Kaingang Rio & KRIO & 53 & Subtropical Forests, Brazil & 27.00 & 52.00 & Marrero et al., 2007 \\
\hline Kaingang Paraná & KPAR & 21 & Subtropical Forests, Brazil & 24.30 & 55.50 & Marrero et al., 2007 \\
\hline Ayoreo & AYO & 91 & Gran Chaco, Paraguay & 19.00 & 60.30 & Dornelles et al., 2004 \\
\hline Aché & ACHE & 63 & Subtropical Forests, Paraguay & 23.70 & 55.90 & Schmitt et al.,, 2004 \\
\hline Ignacianos & IGN & 15 & Lowlands, Bolivia & 15.10 & 66.40 & Bert et al., 2004 \\
\hline Movima & MOV & 12 & Lowlands, Bolivia & 14.26 & 65.53 & Bert et al., 2004 \\
\hline Trinitare & TRI & 11 & Lowlands, Bolivia & 14.00 & 65.00 & Bert et al., 2004 \\
\hline Yuracaré & YUR & 15 & Lowlands, Bolivia & 17.00 & 65.00 & Bert et al., 2004 \\
\hline Aymara - Titicaca & AYM & 96 & Central Andes, Bolivia & 16.30 & 68.80 & Gaya Vidal 2011 \\
\hline Quechuas - Potosi & QUE & 93 & Central Andes, Bolivia & 19.30 & 65.44 & Gaya Vidal 2011 \\
\hline Arequipa & ARE & 22 & Central Andes, Peru & 16.23 & 71.32 & Fuselli et al., 2003 \\
\hline Tayacaja & TAY & 60 & Central Andes, Peru & 12.23 & 74.52 & Fuselli et al., 2003 \\
\hline Quechua - Puno & QPNO & 30 & Central Andes, Peru & 15.50 & 70.01 & Lewis et al., 2007 \\
\hline Aymara - Puno & APNO & 14 & Central Andes, Peru & 15.50 & 70.01 & Lewis et al., 2007 \\
\hline Quechuas - Titicaca & QTT & 37 & Central Andes, Peru & 15.88 & 69.92 & Barbieri et al., 2011 \\
\hline Aymara - Titicaca & ATT & 20 & Central Andes, Peru & 15.85 & 69.96 & Barbieri et al., 2011 \\
\hline
\end{tabular}


Table 2. Native American mtDNA haplogroups distribution in the population samples used in this study. In parenthesis, the absolute frequencies.

\begin{tabular}{|c|c|c|c|}
\hline Haplogroup & Sumampa & Villa Atamisqui & Total \\
\hline $\mathrm{A} 2$ & $0.207 \quad(6)$ & $0.161 \quad(9)$ & $0.185 \quad(15)$ \\
\hline B2 & $0.069 \quad(2)$ & $0.107 \quad(6)$ & $0.098 \quad(8)$ \\
\hline $\mathrm{C} 1$ & 0.310 & $0.482 \quad(27)$ & $0.444 \quad(36)$ \\
\hline D1 & $0.379 \quad(11)$ & $0.196 \quad(11)$ & $0.272 \quad(22)$ \\
\hline
\end{tabular}

Exact $\mathrm{P}$ value $=0.245 \pm 0.006$ (after 100000 Markov steps). 
Table 3. Haplotypes representing the HVR-I mtDNA sequences between 16027-16362np, present in the population samples of Santiago del Estero and shared with other populations from Argentina.

\begin{tabular}{|c|c|c|c|c|}
\hline Haplogroup & Haplotype & $\mathbf{n}$ & Shared with & Polymorphic sites \\
\hline \multirow{5}{*}{ A2 } & h1 (nodal) & 8 & Most of populations & 1611116223162901631916362 \\
\hline & $\mathrm{h} 2$ & 1 & $1 \mathrm{CBA}-5 \mathrm{AZA}$ & 161111618916223162901631916362 \\
\hline & h3 & 4 & 4 CBA - 6 MAP - 1 PIL & 16223162901631916362 \\
\hline & h4 & 1 & - & 16111162901631916362 \\
\hline & h5 & 1 & - & 160861611116223162901631916362 \\
\hline \multirow{6}{*}{ B2 } & h6 & 1 & - & 16092161451615616157161891621716295 \\
\hline & h7 & 1 & $3 \mathrm{CBA}$ & 161891621716357 \\
\hline & h8 (nodal) & 3 & Most of populations & 1618916217 \\
\hline & h9 & 1 & - & 161451615616157161891621716362 \\
\hline & h10 & 1 & - & 16189162171624716261 \\
\hline & $\mathrm{h} 11$ & 1 & - & $160921612616189162141621716355 A$ \\
\hline \multirow{8}{*}{ C1 } & h12 & 11 & 12 CBA - 1 CAT - 3 WFOR & 1605116223162981632516327 \\
\hline & h13 (nodal) & 7 & Most of populations & 16223162981632516327 \\
\hline & h14 & 5 & 1 TFOR & 1613616223162981632516327 \\
\hline & h15 & 2 & 3 CBA & 160511612916223162981632516327 \\
\hline & h16 & 2 & 4 CBA - 1WFOR & 1609216223162981632516327 \\
\hline & h17 & 1 & - & 1622316298163251632716343 \\
\hline & h18 & 1 & - & 16037160921622316260162981632516327 \\
\hline & h19 & 1 & - & 160511618916223162981632516327 \\
\hline
\end{tabular}




\begin{tabular}{|c|c|c|c|c|}
\hline & h20 & 1 & - & $\begin{array}{l}1622316291162981632516327 \\
16051162231625916271162981631116325\end{array}$ \\
\hline & h21 & 2 & 3 WFOR & 16327 \\
\hline & h22 & 2 & - & 161361622316256162981632516327 \\
\hline & h23 & 1 & - & 16172162981632516327 \\
\hline \multirow{6}{*}{ D1 } & h24 (D1j) & 11 & 26 CBA - 1MAP - 6 CAT - 1 PIL - 2 WFOR & 1622316242163111632516362 \\
\hline & h25 (D1j) & 3 & - & 162231624216286163111632516362 \\
\hline & h26 & 5 & 3 CBA - 1 PIL - 2 WFOR & 16223163111632516362 \\
\hline & h27 (D1j) & 1 & $2 \mathrm{CBA}$ & 161571622316242163111632516362 \\
\hline & h28 & 1 & $2 \mathrm{CBA}-1 \mathrm{MAP}$ & 16126162231632516362 \\
\hline & h29 (nodal) & 1 & Most of populations & 162231632516362 \\
\hline
\end{tabular}


Table 4. Analysis of the molecular variance for Native American based on mtDNA HVR-I sequence distribution among Southern Cone populations by geographic region.

\begin{tabular}{|c|c|c|c|c|c|c|}
\hline \multirow[b]{2}{*}{ Region } & \multirow[b]{2}{*}{$\begin{array}{l}\text { Number of } \\
\text { Sequences }\end{array}$} & \multirow[b]{2}{*}{$\begin{array}{l}\text { Number of } \\
\text { Samples }\end{array}$} & \multirow[b]{2}{*}{$\begin{array}{l}\text { Number of } \\
\text { groups }\end{array}$} & \multicolumn{2}{|c|}{$\%$ Variance components ${ }^{*}$} & \multirow[b]{2}{*}{$\begin{array}{l}\text { Among- } \\
\text { groups }\end{array}$} \\
\hline & & & & $\begin{array}{l}\text { Within- } \\
\text { Populations }\end{array}$ & $\begin{array}{l}\text { Among-populations/ } \\
\text { Within-groups }\end{array}$ & \\
\hline Southern Cone & 2016 & 39 & 6 & 75.03 & 16.00 & 8.97 \\
\hline Southern Cone ${ }^{1}$ & 1864 & 37 & 6 & 78.45 & 8.95 & 12.60 \\
\hline Sierras Pampeanas & 464 & 5 & - & 87.91 & 12.09 & - \\
\hline Tierra del Fuego - Patagonia & 345 & 7 & - & 94.06 & 5.94 & - \\
\hline Gran Chaco & 295 & 6 & - & 68.52 & 31.48 & - \\
\hline 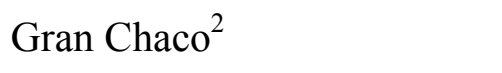 & 204 & 5 & - & 92.44 & 7.56 & - \\
\hline Subtropical Forests & 458 & 7 & - & 62.39 & 37.61 & - \\
\hline Subtropical Forests ${ }^{3}$ & 395 & 6 & - & 76.53 & 23.47 & - \\
\hline Central Andes & 439 & 10 & - & 95.17 & 4.83 & - \\
\hline Lowlands & 53 & 4 & - & 97.23 & $2.77 n s$ & - \\
\hline
\end{tabular}

${ }^{1}$ removing Ayoreo and Aché

${ }^{2}$ removing Ayoreo

${ }^{3}$ removing Aché

*All values other than $n s$ are significant at the $1 \%$ level 


\section{Figure captions}

Figure 1: Map of the Southern Cone of South America and geographic location of the populations studied in Santiago del Estero province. The shaded area corresponds approximately to the Sierras Pampeanas geographic region.

Figure 2. Bidimensional plot showing relative affinities between population samples across the Southern Cone of South America based on Kimura 2-parameters distances calculated from mtDNA HVR-I (stress $=0.110)$.

Figure 3. Median-joining network for haplogroup C1 of 230 haplotypes observed in population from different regions of Argentina. mtDNA motifs of HVS-I between 16,027 and 16,362 positions were used to draw the tree. Each circle represents a different haplotype, and the relative size reflects the frequency of each haplotype. The grey squares represent hypothetical haplotypes not found in this study. The black circles are the haplotypes present in Santiago del Estero populations. The nodal haplotype h13 is characterized by 16223-16298-16325-16327 mutation positions. Haplotypes present in individuals from Santiago del Estero are detailed in Table 3.

Figure 4. Median-joining network for haplogroup D1 of 249 haplotypes observed in population from different regions of Argentina. mtDNA motifs of HVS-I between 16,027 and 16,362 positions were used to draw the tree. Each circle represents a different haplotype, and the relative size reflects the frequency of each haplotype. The black circles are the haplotypes present in Santiago del Estero 
populations. The nodal haplotype h29 is characterized by 16223-16325-16362 mutation positions. Haplotypes present in individuals from Santiago del Estero are detailed in Table 3. 
Figure 1

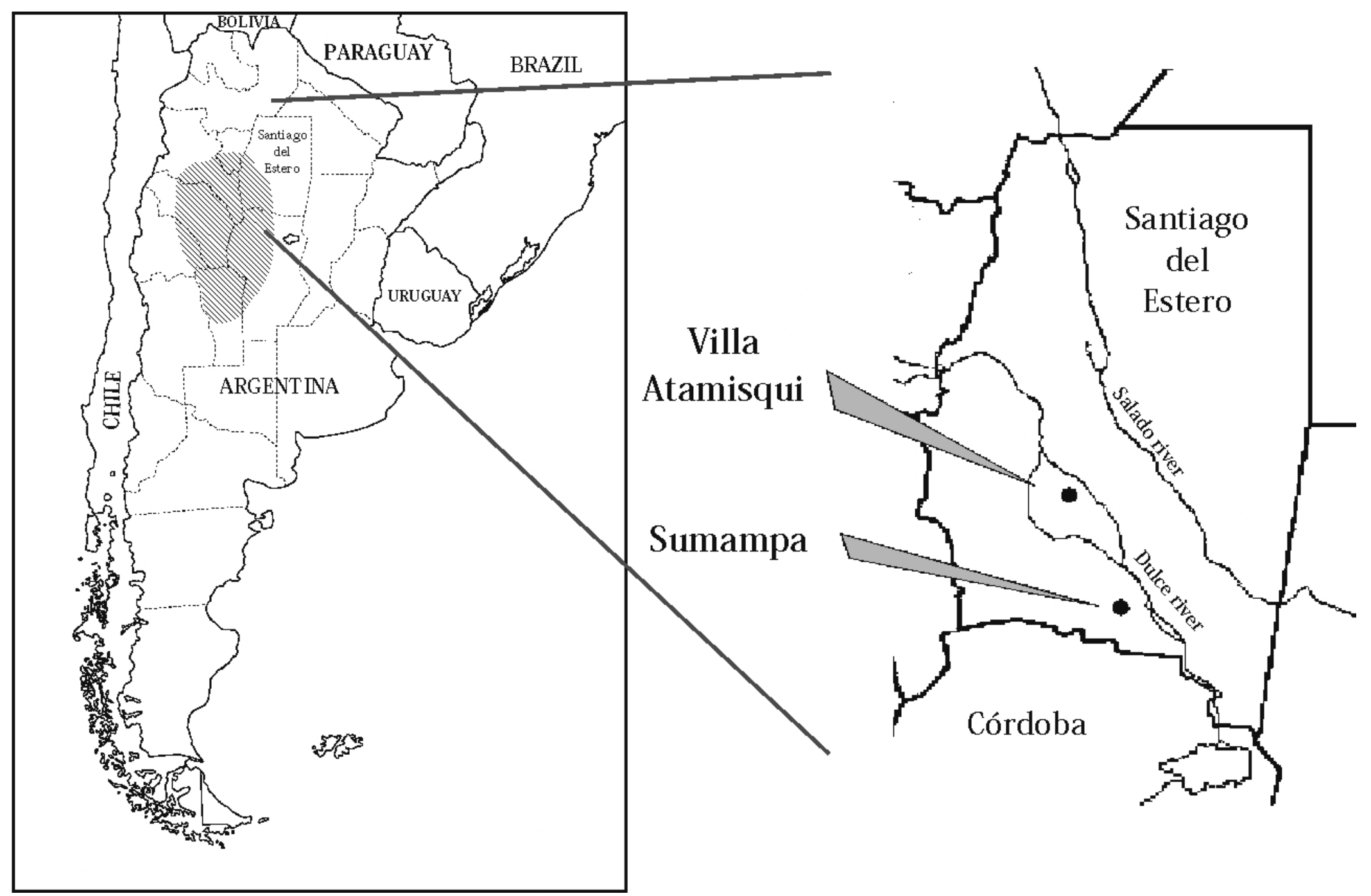




\section{Figure 2}

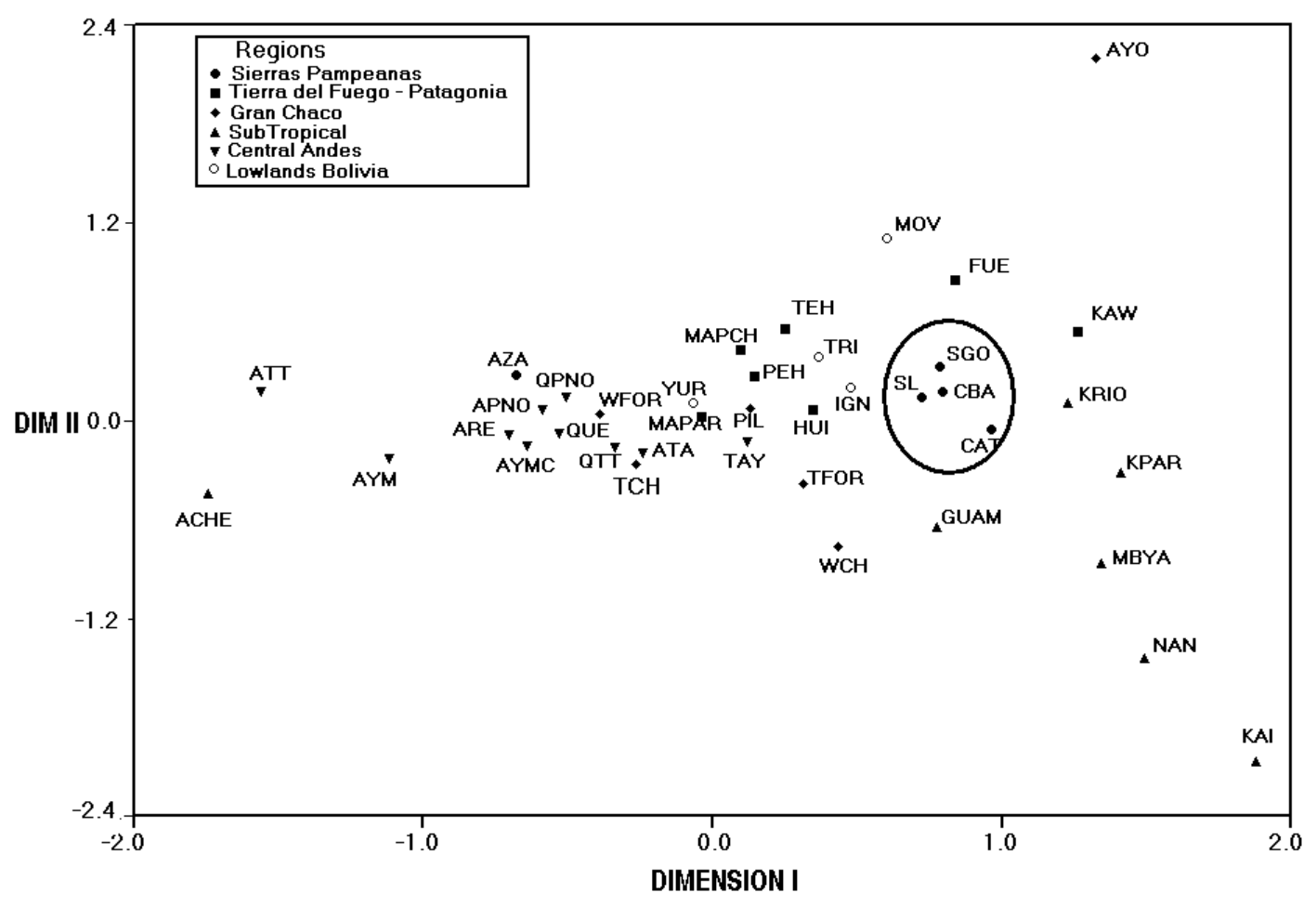


Figure 3

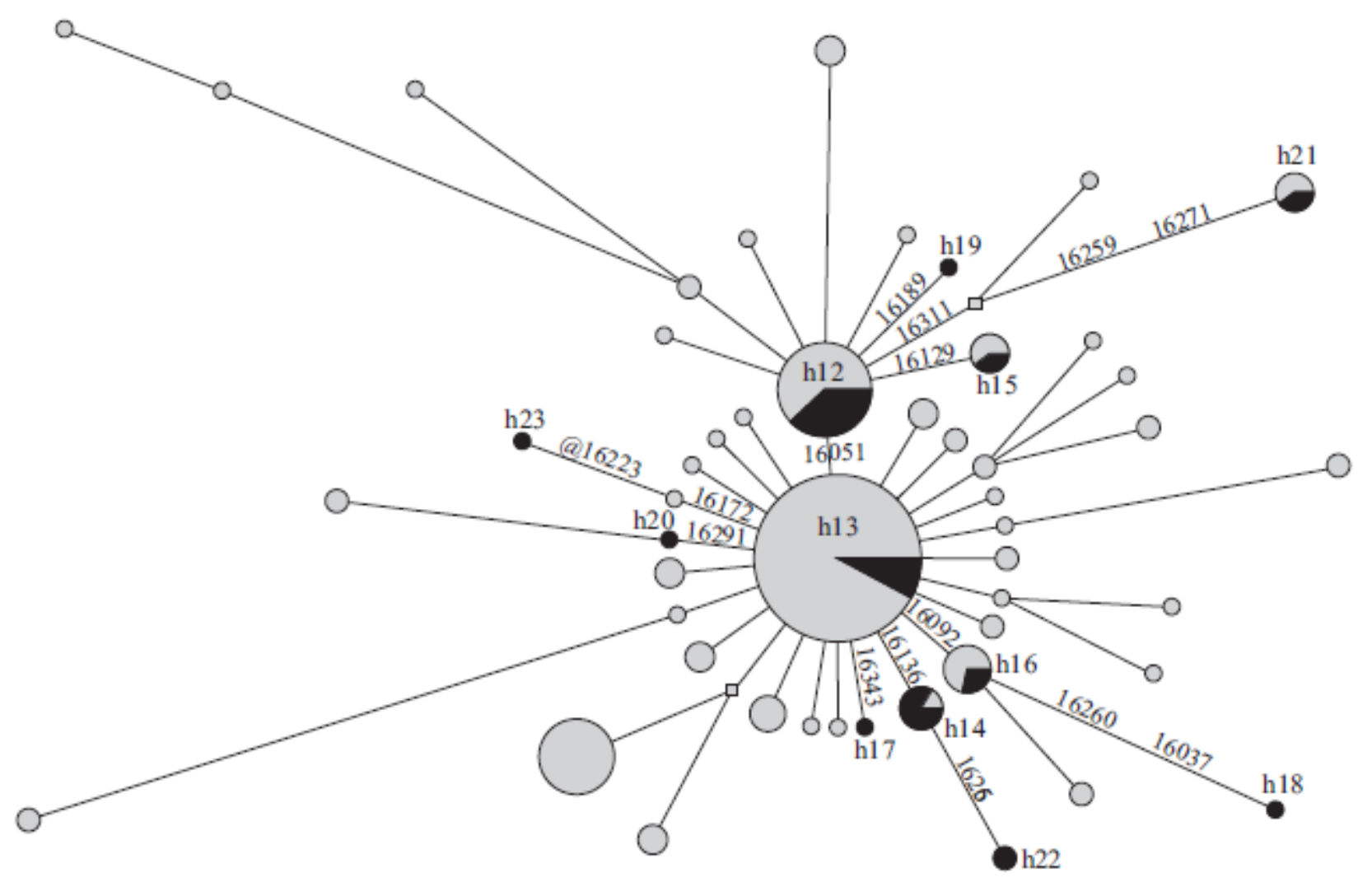




\section{Figure 4}

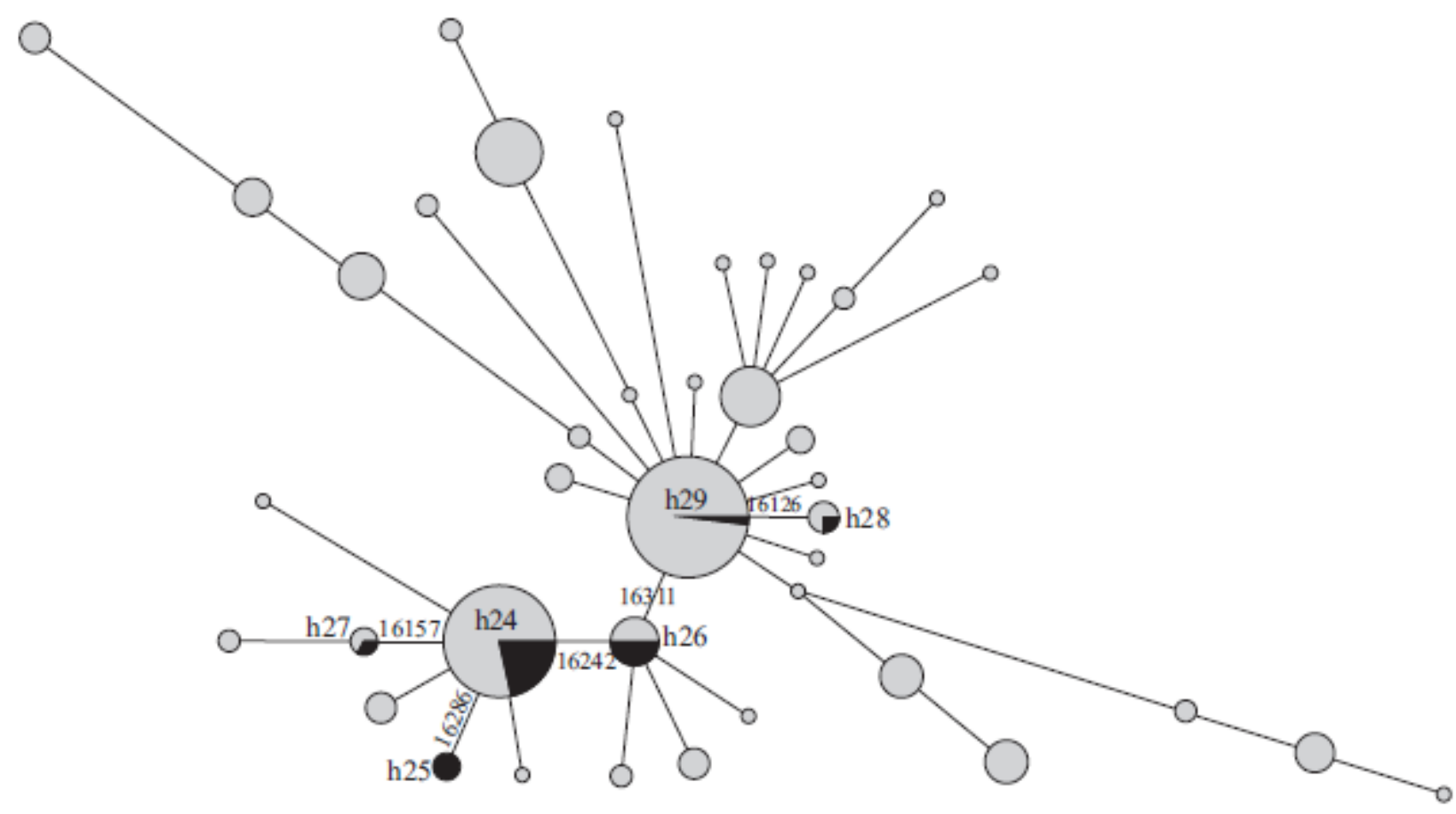


Appendix 1. mtDNA Control Region haplotypes found in both Santiago del Estero population samples.

\section{CONTROL REGION}

\begin{tabular}{|c|c|c|c|c|}
\hline & & & & \\
\hline ID & HG & $\mathbf{N}$ & 16024-16569 & 01-576 \\
\hline SGO1 & $\mathrm{A} 2$ & 3 & 111223290319362 & $6473146153235315+C 523-524 d$ \\
\hline $\mathrm{SGO} 2$ & $\mathrm{~A} 2$ & 2 & 111223290319362 & $6473146152153235263315+C$ \\
\hline $\mathrm{SGO} 3$ & $\mathrm{~A} 2$ & 1 & 111223290319362 & $6473146153235263309+C$ 315+C 523-524d \\
\hline SGO4 & $\mathrm{A} 2$ & 1 & 111189223290319362 & $44+C 6473146153235263309+C C \quad 315+C$ 523-523d \\
\hline SGO5 & $\mathrm{A} 2$ & 3 & 223290319362 & $6473146153235263309+$ CC $315+C$ 523-524d \\
\hline SGO6 & $\mathrm{A} 2$ & 1 & 223290319362 & $6473146153235263309+C$ 315+C 523-524d \\
\hline SGO7 & $\mathrm{A} 2$ & 1 & 111290319362519 & $6473146151153235315+C 523-524 d$ \\
\hline SGO8 & $\mathrm{A} 2$ & 1 & 111223290319362519 & $6473146153210235263315+C \quad 523-524 d$ \\
\hline SGO9 & $\mathrm{A} 2$ & 1 & 086111223290319362526 & $6473146150153235263309+\mathrm{C} 315+\mathrm{C}$ \\
\hline SGO10 & $\mathrm{A} 2$ & 1 & $111223290319362512547550551+\mathrm{G}$ & 73146153263 309+CC 315+C 523-524d \\
\hline SGO11 & $\mathrm{B} 2$ & 1 & 183C 189217357519 & $73195263315+C 499$ \\
\hline SGO12 & $\mathrm{B} 2$ & 1 & $092145156157182 \mathrm{C} 183 \mathrm{C} 189217295519$ & $73263309+\mathrm{C} 315+\mathrm{C} / / 499$ \\
\hline SGO13 & $\mathrm{B} 2$ & 1 & $145156157182 \mathrm{C} 183 \mathrm{C} 189217362381$ & $73263309+\mathrm{CC} 315+\mathrm{C} 499$ \\
\hline SGO14 & $\mathrm{B} 2$ & 3 & $182 \mathrm{C} 183 \mathrm{C} 189217519$ & $73143146165263315+C 499$ \\
\hline SGO15 & $\mathrm{B} 2$ & 1 & $182 \mathrm{C} 183 \mathrm{C} 189217247261$ & $73146263309+\mathrm{CC} 315+\mathrm{C}$ \\
\hline SGO16 & $\mathrm{B} 2$ & 1 & $092126182 \mathrm{C} 183 \mathrm{C} 189214217355$ A 519 & $73152309+\mathrm{CC} 315+\mathrm{C} / / 499$ \\
\hline SGO17 & C1d & 2 & 051223298325327 & 73194195 249d 263 290-291d 309+C 315+C 489 523-524d \\
\hline SGO18 & C1d & 2 & 051223298325327 & 73194195204 249d 263 290-291d 309+C 315+C 489 523-524d \\
\hline SGO19 & C1d & 1 & 051223298325327 & 73194195 249d 263 290-291d 309+C // 523-524d \\
\hline SGO20 & C1d & 2 & 051223298325327 & 73194195 249d 263 290-291d 315+C 489 523-524d \\
\hline SGO21 & C1d & 1 & 051223298325327 & 73195204 249d 263 290-291d 309+CC 315+C 489 523-524d \\
\hline SGO22 & C1d & 2 & 051129223298325327 & 73194195 249d 263 290-291d 309+C 315+C 489 523-524d \\
\hline SGO23 & C1d & 1 & 051223298325327519 & 73194195 249d 263 290-291d 309+CC 315+C 489 523-524d \\
\hline SGO24 & C1d & 1 & 051223298325327519 & 73194195204 249d 263 290-291d 309+CC 315+C 489 523-524d \\
\hline SGO25 & C1d & 1 & 051223298325327519 & 73194195 249d 263 290-291d 309+C 315+C 489 523-524d 573+CCC \\
\hline
\end{tabular}




\begin{tabular}{|c|c|c|}
\hline SGO26 & C1d & $1 \quad 051189223298325327$ \\
\hline SGO27 & Cld & 1051223259271298311325327 \\
\hline SGO28 & C1d & 1051223259271298311325327519 \\
\hline SGO29 & $\mathrm{C} 1 \mathrm{~b}$ & 1223298325327519 \\
\hline SGO30 & $\mathrm{C} 1 \mathrm{~b}$ & 1223298325327519 \\
\hline SGO31 & $\mathrm{C} 1 \mathrm{~b}$ & 2223298325327519 \\
\hline SGO32 & $\mathrm{C} 1 \mathrm{~b}$ & 1223298325327519 \\
\hline SGO33 & $\mathrm{C} 1 \mathrm{~b}$ & 1223298325327519 \\
\hline SGO34 & $\mathrm{C} 1 \mathrm{~b}$ & 3136223298325327519 \\
\hline SGO35 & $\mathrm{C} 1 \mathrm{~b}$ & 1136223298325327519 \\
\hline SGO36 & $\mathrm{C} 1 \mathrm{~b}$ & 1136223298325327519 \\
\hline SGO37 & $\mathrm{C} 1 \mathrm{~b}$ & 2136223256298325327519 \\
\hline SGO38 & $\mathrm{C} 1 \mathrm{~b}$ & 2092223298325327 \\
\hline SGO39 & $\mathrm{C} 1 \mathrm{~b}$ & 1037092223260298325327 \\
\hline SGO40 & $\mathrm{C} 1 \mathrm{~b}$ & 1223291298325327519 \\
\hline SGO41 & $\mathrm{C} 1 \mathrm{~b}$ & 1223298325327390 \\
\hline SGO42 & $\mathrm{C} 1 \mathrm{~b}$ & 1172298325327526 \\
\hline SGO43 & $\mathrm{C} 1 \mathrm{c}$ & 1 (15930) 223298325327343 \\
\hline SGO44 & D1 & 1223325362 \\
\hline SGO45 & $\mathrm{D} 1 \mathrm{j}$ & 4223242311325362 \\
\hline SGO46 & $\mathrm{D} 1 \mathrm{j}$ & 1223242311325362 \\
\hline SGO47 & $\mathrm{D} 1 \mathrm{j}$ & 1223242311325362 \\
\hline SGO48 & $\mathrm{D} 1 \mathrm{j}$ & 2223242311325362 \\
\hline SGO49 & $\mathrm{D} 1 \mathrm{j}$ & 1223242311325362 \\
\hline SGO50 & $\mathrm{D} 1 \mathrm{j}$ & 1223242311325362 \\
\hline SGO51 & $\mathrm{D} 1 \mathrm{j}$ & 1223242311325362 \\
\hline SGO52 & $\mathrm{D} 1 \mathrm{j}$ & 2223242286311325362 \\
\hline SGO53 & $\mathrm{D} 1 \mathrm{j}$ & 1223242286311325362 \\
\hline SGO54 & $\mathrm{D} 1 \mathrm{j}$ & 1157223242311325362 \\
\hline SGO55 & D1 & 1223311325362391 \\
\hline SGO56 & D1 & 1223311325362391 \\
\hline
\end{tabular}

73194195 249d 263 290-291d 309+C 315+C 489 523-524d 73194195 249d 263 290-291d 315+C 489 523-524d 73151194195 249d 263 290-291d 315+C 489 523-524d 73146150207 249d 263 290-291d 309+C 315+C 489493 523-524d 73146 249d 263 290-291d 309+C 315+C 489493 523-524d 574 73146 249d 263 290-291d 309+C 315+C 489493 523-524d 73146 249d 263 290-291d 309+CC 315+C 489493 523-524d 73150207 249d 263 290-291d 309+CC 315+C 489493 523-524d 73146 249d 263 290-291d 309+C 315+C 489493 523-524d 7394146 249d 263 290-291d 309+C 315+C 489493 523-524d 73146 249d 263 290-291d 315+C 489493 523-524d 73146153 249d 263 290-291d 309+C 315+C 489493 523-524d 549 73 249d 263 290-291d 309+C 315+C 489493 523-524d 73 249d 263 290-291d 309+C 315+C 489493 523-524d 73150 249d 263 290-291d 309+C 315+C 489493 523-524d 73150194 249d 263 290-291d 309+C 315+C 489493 73153 249d 263 290-291d 315+C 489493 523-524d 73146249 d 263 290-291d 315+C 489 $73185263315+\mathrm{C} 489$ $73152263315+\mathrm{C} 489524+\mathrm{AC}$ $73152263309+\mathrm{C} 315+\mathrm{C} 489$ 73152263 309+C 315+C 489 524+AC 538C $73152235263315+\mathrm{C} 489$ $73152235263309+\mathrm{CC} 315+\mathrm{C} / / 489$ 42+G 73 106-111d 152212263 309+C 315+C 489 73 106-111d $152212263309+\mathrm{C} 315+\mathrm{C} 489$ 73 106-111d $152212263309+\mathrm{C} 315+\mathrm{C} 489$ 73 106-111d $152212263309+\mathrm{C} 315+\mathrm{C} 374489$ $73152263309+$ CC $315+C 489$ $73152200225263309+\mathrm{C} 315+\mathrm{C} 489$ 523-524d $73152263309+\mathrm{C} 315+\mathrm{C} 489523-524 \mathrm{~d}$ 


$\begin{array}{lclll}\text { SGO57 } & \text { D1 } & 2 & 223311325362391 \\ \text { SGO58 } & \text { D1 } & 1 & 223311325362391519 \\ \text { SGO59 } & \text { D1 } & 1 & 126223325362 \\ \text { SGO60 } & \text { K } & 1 & 224311519 \\ \text { SGO61 } & \text { H } & 1 & 162192 \\ \text { SGO62 } & \text { U7-Y? } & 1 & 126231318 T 519 \\ & & & 37129140184187189223274278294301 \\ \text { SGO63 } & \text { L1c4 } & 1 & 311360519\end{array}$

SGO57 D1 2223311325362391

1224311519

SGO61 H $\quad 1 \quad 162192$

SGO63 L1c4 13311360519
$73152200263309+\mathrm{C} 315+\mathrm{C} 489523-524 d$ $73152200263309+\mathrm{C} 315+\mathrm{C} 489523-524 d$ $1055566473263279309+\mathrm{C} 315+\mathrm{C} 489$

//

$263315+\mathrm{C}$

$73146152263309+C 315+C$ 523-524d

73152182186 A 189 C $195198247263297315+$ C 316 